\title{
FOLLOWING IN THEIR FOOTSTEPS: COMPARING INTEREST PARITY CONDITIONS IN CENTRAL EUROPEAN ECONOMIES TO THE EURO COUNTRIES
}

\author{
KASHIF S. MANSORI \\ CESIFO WORKING PAPER NO. 1020 \\ CATEgory 6: Monetary Policy and InTERnational FinANCE \\ August 2003
}

\footnotetext{
An electronic version of the paper may be downloaded

- from the SSRN website: www.SSRN.com

- from the CESifo website: www.CESifo.de
} 


\title{
FOLLOWING IN THEIR FOOTSTEPS: COMPARING INTEREST PARITY CONDITIONS IN CENTRAL EUROPEAN ECONOMIES TO THE EURO COUNTRIES
}

\begin{abstract}
This paper investigates capital market integration in the major Central European emerging economies by testing the covered and uncovered interest parity conditions vis-à-vis the U.S. dollar and the DM/euro. The results for the Central European economies since 1997 are contrasted against those of the euro countries during the period preceding the introduction of the euro. This allows a comparison of conditions in the capital markets in the Central European economies versus those in the pre-euro EU. The results suggest that capital mobility and exchange rate market efficiency in Central Europe are remarkably similar to conditions in the EU during the 1990s.
\end{abstract}

JEL Code: F21, F31, F36.

Keywords: covered interest parity, uncovered interest parity, Central Europe, EU enlargement.

\author{
Kashif S. Mansori \\ Department of Economics \\ Colby College \\ 5230 Mayflower Hill \\ Waterville, ME 04901 \\ U.S.A. \\ kmansori@colby.edu
}




\section{Introduction}

International capital mobility is of obvious importance for many well-known reasons, regarding both economic theory and policy. Tests used to gauge the degree of capital market integration between countries generally look either at quantities, measuring the volume of capital flows, or prices, which examines the degree to which financial prices have equalized between countries. Exchange rates and interest rates are the most commonly used financial prices for this purpose.

Little work has been done to apply such tests to the Central European emerging economies (CEEEs), however. This paper uses short-term interest rate and exchange rate data from the three largest emerging economies in central Europe - Poland, Hungary, and the Czech republic - to test the covered interest parity condition against both the U.S. and the euro zone. This paper therefore provides one of the first systematic examinations of the degree of capital mobility of the CEEEs using exchange rate data.

In addition, this paper also examines exchange rate market efficiency in the CEEEs, in two related ways. First, I use the uncovered interest parity condition to check for the existence of a "forward puzzle." Second, I test the efficiency of the currency markets in those countries by examining the predictive power of the forward premium. This paper therefore uses exchange rate data to perform three distinct sets of tests, each containing different information about the efficiency and integration of the capital markets of the major central European countries: the covered interest parity condition (CIP), the uncovered interest parity condition (UIP), and the forward market efficiency tests. In all cases, the results for the CEEEs is compared against the estimates for the euro countries during the period leading up to the adoption of the euro. This 
provides a good benchmark to gauge the similarity of the experience of the CEEEs with that of the pre-euro EU countries.

Information about the exchange rate markets in the CEEEs is important for several reasons. Capital mobility and exchange rate market efficiency both may have effects on future private investment flows into those emerging economies. Policy makers in the CEEEs need such information to better understand the effects of fiscal and monetary policy. But perhaps most importantly, policy makers in the CEEEs and the EU need to have a sense for whether those countries' accession to the EU and adoption of the euro in 2004 will cause a dramatic change in the financial markets of those countries, or whether the transition can be expected to be as smooth as the adoption of the euro proved to be for the capital markets of the current euro countries. ${ }^{1}$ Put bluntly: are capital markets in the CEEEs ready to join the EU?

This paper also makes a contribution to the evidence related to the theory of exchange rate behavior. In particular, by testing UIP, this paper adds to the body of literature addressing the existence of a "forward puzzle," where spot exchange rates move in the opposite direction from that predicted by theory.

The paper is organized as follows. In section two I discuss the theory and previous literature in this area. Section three covers the methodology and results for the CIP tests. Section four does the same for the UIP tests. Section five investigates the behavior of the risk premiums more closely using tests of the forward premium. The final section summarizes the findings and conclusions of the three sets of tests.

\footnotetext{
${ }^{1}$ Note that accession treaties for 10 Central and Eastern European nations to join the EU were signed on March 16, 2003 in Athens. On May 1, 2004 the following 10 countries will officially join the EU: Cyprus, Czech Republic, Estonia, Hungary, Latvia, Lithuania, Malta, Poland, Slovak Republic, and Slovenia. (European Parliament Website)
} 


\section{Background Theory and Literature}

Relatively little research has been done to examine the exchange rate markets of the CEEEs. Dickinson and Mullineux (2001) provide an overview of much of the recent literature on financial integration between the CEEEs and the EU. They point out that most of this work consists of analysis of the effect of those countries' monetary and exchange rate policy on financial markets, and the impact of increasing convergence of the financial systems of the CEEEs with those of the EU.

Claessens, Oks, and Polastri (1998) provide a good general description of the magnitudes and types of capital flowing into the former Soviet bloc countries during the early and mid 1990s. Their primary interest, however, is in understanding the motivations for capital flows in those countries, rather than the degree to which such capital flows represent complete integration with world capital markets. I therefore try to augment our understanding of the degree of capital market integration and exchange rate market efficiency in the CEEEs by testing CIP, UIP, and forward market efficiency.

\subsection{Covered interest parity}

The first test I use is the covered interest parity (CIP) condition. CIP states that capital flows should equalize returns on assets of equal maturity and default risk across countries, once currency risk has been eliminated by covering the transaction through the use of forward contracts. Since the transaction is then nearly riskless (only subject to default risk), CIP is usually considered to be an arbitrage condition, and significant deviations from CIP are interpreted as reflecting barriers to cross-border capital flows. As pointed out by Obstfeld 
(1995), the CIP test is therefore one of the most straightforward ways to gauge the extent of capital mobility between countries.

Numerous studies have used the CIP condition to measure such barriers. Some recent examples where this technique has been applied to Europe include Holmes and $\mathrm{Wu}$ (1997) and Holmes (2001). In those papers CIP is used to measure the degree of capital mobility between several EU countries during the 1990s. In both papers, onshore and offshore (eurocurrency) interest rates are tested for CIP by checking for unit roots in deviations from CIP, using both a conventional augmented Dickey-Fuller test and a panel-data test. In general, CIP holds between EU countries and Germany, though for some countries this is only true when eurocurrency interest rates are used instead of government bond rates. This is attributed to the fact that eurocurrency rates are free from government intervention in the form of capital controls. Kumhof (2001) uses a similar technique applied to daily data to examine the degree of integration with world capital markets for three emerging market economies: Thailand, Indonesia, and Mexico. He finds strong evidence for CIP in those countries. Szeidl (2001) provides an example of the use of CIP to examine Eastern European countries. He uses CIP to test the credibility of the exchange rate regimes of Hungary and Poland during a 21 month period around the time of the Russian financial crisis of 1998. He interprets his CIP evidence as indicating that the exchange rate regimes were seen as fairly credible, but more so for Poland after the Russian crisis than for Hungary. However, his focus is restricted to the 1997-98 period, and he does not go into the deeper question of measuring overall capital market integration. 


\subsection{Uncovered interest parity}

Uncovered interest parity departs from CIP by not covering the exchange rate exposure of a cross-border investment with a forward currency contract, thus leaving the investor at risk of future spot exchange rates that differs from expectations. If currency markets operate efficiently and UIP holds, then interest differentials should predict the movement of the spot exchange rate over time. UIP therefore jointly tests capital mobility and the efficiency of exchange rate markets.

Typically, research has found a "forward puzzle," where positive interest differentials are associated with appreciating currencies, rather than depreciating currencies as UIP predicts. ${ }^{2}$ For example, Flood and Rose (1996) use the UIP test to examine European currencies in both fixed and flexible exchange rate regimes from 1981 to 1994 . The null hypothesis of forward unbiasedness is rejected in all instances. However, they find that a large amount of the forward puzzle vanishes for fixed currency regimes.

More recent work suggests that the forward puzzle diminished in the mid to late 1990s. Using data running up through 1996, Choudry (1999) investigates forward market efficiency using UIP, and finds that there is no forward puzzle in at least some cases. Bansal and Dahlquist (2000) use pooled time series data from 28 developed and emerging economies during the 1990s, and find that the forward puzzle disappears for many emerging economies. Similar work was done by Flood and Rose (2001), who apply the UIP test to a sample of 23 developing and developed countries through the 1990s. They find that UIP tended to work better through the 1990s than during earlier periods, and that it worked better for countries that faced financial crises. However, they found no systematic difference in UIP between developed and emerging economies. 
On the other hand, Meredith and Ma (2002) call into question this emerging result that the forward puzzle has diminished recently. They present data suggesting that, for the G-7 countries at least, tests of UIP still present us with a forward puzzle in the years leading up to 2000. Only the paper by Bansal and Dahlquist, however, includes data from the CEEEs, and their paper does not examine them individually but rather pools them with several other emerging economies. The current paper will therefore try to fill that gap by examining the forward puzzle specifically in the case of the three CEEEs.

\subsection{Forward market efficiency}

Some previous work has tried to delve deeper into the forward puzzle by decomposing variations in the forward premium into two components: deviations in the expected future spot rate, and deviations in the risk premium. This was first done by Fama (1984), and was applied to the major European countries by DeGrauwe (1989) and (1996).

Fama (1984) concludes that most of the variation in forward rates was due to variation in risk premiums. This result is echoed by DeGrauwe (1989), but he also finds that this result diminishes in the case of the European countries that were members of the EMS during the 1980s. His conclusion is that fixed exchange rates provide an effective anchor to limit the variation in risk premiums.

A similar analysis of the CEEEs will provide insight into whether they behave like the members of the EMS did. In other words, we should be able to discern whether the fixed exchange rate regimes of the CEEEs reduced the volatility of the risk premiums just as they did for the euro countries. In addition to yielding information about the volatility of risk premiums

\footnotetext{
${ }^{2}$ See Meredith and Ma (2002) for an overview of these sorts of results in previous literature.
} 
in those countries, this will tell us something about the credibility of the CEEE exchange rate regimes.

When put together, the three types of tests should provide a more complete picture of how the exchange rates of the CEEEs behave, and thus how integrated and efficient their capital markets are. I now proceed to describe the methodology and results of the three sets of tests.

\section{CIP Tests}

\subsection{Methodology and data}

If capital is free to flow between countries, then returns on assets of equal riskiness in two countries should be the same. The CIP condition can therefore be expressed as

$$
r_{t}=r_{t}^{*}\left(f_{t}-s_{t}\right) / s_{t}
$$

where $r_{t}$ is the return on a domestic asset, $r_{t}{ }^{*}$ is the nominal return (in local currency) of a foreign asset, $s_{t}$ is the spot exchange rate, and $f_{t}$ is the forward exchange rate the appropriate number of periods ahead. Normally the assets being compared are essentially riskless, such as short term government bond or money market rates, so the CIP is a simple arbitrage condition. It therefore should hold whenever capital is free to flow between countries and thus arbitrage away any differences between the two rates of return. In practice, transactions costs, information costs, differential tax treatment, and government interference or regulations may preclude CIP from holding perfectly.

The data consists of monthly data for exchange rates and interest rates. Spot exchange rates are taken from the end-of-period, and forward exchange rates are 30 day forward rates. Both exchange rates are against the US dollar; the DM (or euro) to dollar exchange rate is used 
to calculate spot and forward rates for each currency against the DM/euro. ${ }^{3}$ One month treasury bill interest rates are used to estimate the 30 day rate of return in each country.

Each test is run individually for each country against both the US dollar and the DM (before January 1999) or euro (from January 1999 onward). In order to provide a benchmark against which to measure the CEEEs, I run first run each test for the four largest euro countries (excluding Germany) during the five-year period leading up to the adoption of the euro, 1994:01 to $1998: 12$. This period was chosen for several reasons. First, the Maastricht treaty, which came into effect in November 1993, established the Single European Market including, among other things, the complete abolition of capital controls between EU member states. Second, by 1994 most of the major EMS exchange rate crises of the early 1990s had passed, and the euro countries began to move more credibly toward the adoption of the euro. Finally, the progression toward the adoption of the euro was codified in the Maastricht convergence criteria, which took effect with the Maastricht treaty of November 1993.

Then the test is run on the three major CEEEs. The entire data set covers the period from April 1997 to December 2002. ${ }^{4}$ The test is also run on the sub-period 1999:01 through 2002:12, which represents the period when the CEEEs were actively moving toward accession to the EU and euro with the adoption of Accession Partnership Agreements in 1998.

Following Holmes, I test CIP using a unit root test. Let $u_{t}$ represent deviations from CIP, defined as:

$$
u_{t}=\left(r_{t}-r_{t}^{*}\right)-\left(f_{t}-s_{t}\right)
$$

where $r_{t}$ is the 30 day return in the home country, $r_{t}{ }^{*}$ is the 30 day return in the foreign country (either the U.S. or Germany), and the forward and spot exchange rates are expressed in log form.

\footnotetext{
${ }^{3}$ Obviously this assumes perfect equalization of cross exchange rates for the dollar and DM/euro. To the degree that this does not hold perfectly, this procedure may introduce slight errors in the data, as noted by Lemmen (1998).
} 
If CIP holds, then any deviations from $u_{t}=0$ should be quickly erased. The null hypothesis is that $u_{t}$ is characterized by a unit root process (so that deviations from CIP persist) which would be evidence against CIP. The specific equation tested is therefore:

$$
\Delta \mathrm{u}_{\mathrm{t}}=\alpha+\beta \mathrm{u}_{\mathrm{t}-1}+\varepsilon_{\mathrm{t}}
$$

\subsection{Results}

As a benchmark, the CIP test is first run for the euro countries during the period January 1994 through December 1998, the last month that they had individual currencies. The results of estimations of equation (3) for four major euro countries are presented in Table 1.

\section{Table 1: CIP results for euro countries}

\begin{tabular}{|l|ccc|ccc|}
\hline 1994:01 to 1998:12 & \multicolumn{3}{|c|}{ vs. US \$ } & \multicolumn{3}{c|}{ vS. DM } \\
& $\boldsymbol{\beta}$ & SE & $\mathbf{r}^{2}$ & $\boldsymbol{\beta}$ & SE & $\boldsymbol{r}^{\mathbf{2}}$ \\
\hline France & $-\mathbf{1 . 0 9 ^ { * * }}$ & 0.12 & 0.55 & $-\mathbf{1 . 6 8 ^ { * * }}$ & 0.12 & 0.84 \\
Netherlands & $-\mathbf{0 . 9 5 ^ { * * }}$ & 0.13 & 0.48 & $\mathbf{- 1 . 4 7 ^ { * * }}$ & 0.16 & 0.75 \\
Spain & $-\mathbf{0 . 8 9 ^ { * * }}$ & 0.12 & 0.45 & $\mathbf{- 1 . 3 7 ^ { * * }}$ & 0.16 & 0.69 \\
Italy & $-\mathbf{0 . 4 4 ^ { * * }}$ & 0.12 & 0.24 & $-\mathbf{1 . 4 9 * *}$ & 0.11 & 0.75 \\
\hline
\end{tabular}

$*$ = significantly different from zero at the $90 \%$ level; $* *=$ significant at the $95 \%$ level $\mathrm{SE}=$ White-corrected standard errors of the coefficient.

The coefficients for the unit-root tests against both the US dollar and the DM are highlighted in boldface. These results indicate that the null hypothesis of a unit root in $\mathrm{u}_{\mathrm{t}}$ is rejected for all countries at the $95 \%$ level over these sample periods. This is significantly stronger than the results of Holmes (2001), who found that CIP held for these EU countries against the US dollar only in the case of eurocurrency assets, not treasury bills. The likely explanation for this is the different periods examined; Holmes' sample runs from 1990 through 1998, whereas our sample begins with 1994, thus excluding the extreme volatility in the

\footnotetext{
${ }^{4}$ Most forward exchange rate data comes from the IMF. Forward rates for the CEEEs come from Olsen Data AG.
} 
European currency markets in the early 1990 s. $^{5}$ It is interesting to note that, in each case, the coefficients are significantly larger against the DM than against the dollar. This suggests faster reversion to $u_{t}=0$ against Germany, and thus may imply greater capital market integration with Germany than with the US, a conclusion that would certainly agree with prior expectations.

Next the same test is run on the CEEEs, over the period running from April 1997 through December 2002. Those results are contained in table 2.

Table 2: CIP results for the CEEEs

\begin{tabular}{|l|ccc|ccc|}
\hline 1997:04 to 2002:12 & \multicolumn{3}{|c|}{ vs. US \$ } & \multicolumn{3}{c|}{ vs. DM/euro } \\
& $\boldsymbol{\beta}$ & SE & $\boldsymbol{r}^{\mathbf{2}}$ & $\boldsymbol{\beta}$ & SE & $\mathbf{r}^{\mathbf{2}}$ \\
\hline Czech Rep. & $-\mathbf{1 . 0 0 ^ { * * }}$ & 0.20 & 0.50 & $\mathbf{- 1 . 5 0 ^ { * * }}$ & 0.14 & 0.75 \\
Hungary & $-\mathbf{0 . 8 2 ^ { * * }}$ & 0.15 & 0.41 & $\mathbf{- 1 . 4 4 ^ { * * }}$ & 0.10 & 0.72 \\
Poland & $-\mathbf{0 . 5 1 ^ { * * }}$ & 0.16 & 0.25 & $\mathbf{- 1 . 4 3 ^ { * * }}$ & 0.15 & 0.71 \\
\hline
\end{tabular}

$*=$ significantly different from zero at the $90 \%$ level; ** = significant at the $95 \%$ level $\mathrm{SE}=$ White-corrected standard errors of the coefficient.

The most striking thing about these results is their similarity to those of the euro countries. Again, the null hypothesis is rejected in each case against both the US and Germany, and the coefficients are of very similar magnitude to those of the euro countries. Interestingly, once again we see that the coefficients are significantly larger against the DM than against the dollar, suggesting capital markets that are closer to the euro area than to the US. More generally, we can conclude from these results that according to CIP, capital mobility of the CEEEs over the past 6 years has been comparable to that of the euro countries during the years leading up to the introduction of the euro.

A panel data unit-root test was run for both groups of countries as well, following the technique developed by Im, Peseran, and Shin (1997). The advantage of this pooled test is that it

\footnotetext{
${ }^{5}$ A second difference is that Holmes used 3 month rates instead of 1 month rates, though it is unclear why this
} 
increases the power of the test to discriminate between unit root processes and near unit root

processes. Since the individual country regressions all rejected the null hypothesis of a unit root, it is not surprising that the panel test simply confirmed the results of the individual country regressions; we can conclude with confidence that deviations from CIP revert to zero for the CEEEs just as they do for the euro countries.

I also break the full period into two sub-periods: 1997:04 to 1998:12 and 1999:01 to 2002:12. As discussed in the previous subsection, this split coincides with the introduction of the euro in the EU, and with the adoption by the three CEEEs of Accession Partnership agreements with the EU. Those results, contained in tables 3 and 4, suffer somewhat from a loss of power due to the low number of observations, especially in the first sub-period. Comparing the two sub-periods suggests some weak evidence for a strengthening of CIP in the second subperiod compared to the first, but otherwise show no major differences from the results of the entire sample. The pooled unit-root test addresses the problem of a low number of observations in the first sub-period, resulting in similar coefficients and lower standard errors.

Table 3: CIP results for the CEEEs, pre-1999

\begin{tabular}{|l|ccc|ccc|}
\hline 1997:04 to 1998:12 & \multicolumn{3}{|c|}{ vS. US \$ } & \multicolumn{3}{c|}{ vS. DM } \\
& $\boldsymbol{\beta}$ & SE & $\mathbf{r}^{2}$ & $\boldsymbol{\beta}$ & SE & $\boldsymbol{r}^{2}$ \\
\hline Czech Rep. & $-\mathbf{1 . 0 3}$ & 0.22 & 0.52 & $-1.44^{* *}$ & 0.16 & 0.72 \\
Hungary & $-\mathbf{0 . 0 1}$ & 0.05 & 0.46 & $-1.41^{* *}$ & 0.10 & 0.70 \\
Poland & $-\mathbf{0 . 5 0 ^ { * }}$ & 0.26 & 0.26 & $-1.44^{* *}$ & 0.16 & 0.72 \\
& & & & & & \\
Pooled results & $-\mathbf{0 . 8 3 ^ { * * }}$ & 0.19 & 0.41 & $-1.43^{* *}$ & 0.08 & 0.71 \\
\hline
\end{tabular}

$*=$ significantly different from zero at the $90 \%$ level; $* *=$ significant at the $95 \%$ level $\mathrm{SE}=$ White-corrected standard errors of the coefficient.

should cause significantly different results. 
Table 4: CIP results for the CEEEs, post-1999

\begin{tabular}{|l|ccc|ccc|}
\hline 1999:01 to 2002:12 & \multicolumn{3}{|c|}{ vS. US \$ } & \multicolumn{3}{c|}{ vs. euro } \\
& $\boldsymbol{\beta}$ & SE & $\mathbf{r}^{\mathbf{2}}$ & $\boldsymbol{\beta}$ & SE & $\mathbf{r}^{\mathbf{2}}$ \\
\hline Czech Rep. & $-\mathbf{1 . 0 0 ^ { * * }}$ & 0.23 & 0.50 & $\mathbf{- 1 . 5 2 ^ { * * }}$ & 0.17 & 0.76 \\
Hungary & $\mathbf{- 0 . 8 7 ^ { * * }}$ & 0.16 & 0.44 & $\mathbf{- 1 . 4 4 ^ { * * }}$ & 0.13 & 0.72 \\
Poland & $-\mathbf{0 . 5 1 ^ { * * }}$ & 0.14 & 0.30 & $-\mathbf{0 . 9 8 ^ { * * }}$ & 0.31 & 0.70 \\
& & & & & & \\
Pooled results & $-\mathbf{0 . 9 5 ^ { * * }}$ & 0.13 & 0.48 & $-\mathbf{- 1 . 4 9 ^ { * * }}$ & 0.11 & 0.75 \\
\hline
\end{tabular}

$*$ = significantly different from zero at the $90 \%$ level; $* *=$ significant at the $95 \%$ level $\mathrm{SE}=$ White-corrected standard errors of the coefficient.

The conclusion is that CIP has held just as well for the CEEEs during the past several years as it did for the euro countries during the lead-up to their adoption of the euro. This evidence thus suggests that the CEEEs have capital markets that are fully integrated into the world economy, alleviating concerns about that aspect of their accession to the EU and adoption of the euro.

\section{UIP Tests}

\subsection{Methodology and data}

As mentioned in section 2.2, UIP relies on the notion that the forward exchange rate should be equal to the expected future spot rate. In practice, however, UIP rarely holds, and this failure to hold is attributed to the existence of a risk premium in the future rate. The UIP condition can therefore be written as

$$
r_{t}=r_{t}^{*}\left(E\left(s_{t+1}\right)-s_{t}\right) / s_{t},+\rho_{t}
$$

where $\rho_{t}$ is a potentially time-varying risk premium to reward investors for the uncertainty surrounding the actual future spot rate $s_{t+1}$.

Unlike the CIP test, the UIP test is not only a test of capital mobility. Because the expected future spot rate $E_{t}\left(s_{t+1}\right)$ can not be observed directly, in practice the ex post observed 
spot rate $s_{t+1}$ is used as a proxy for the expected future spot rate. A test of UIP therefore jointly tests two underlying assumptions: that there is capital mobility, and that exchange rates efficiently embody expectations that are not systematically incorrect. If currency markets are efficient, so that the forward rate is an unbiased predictor of the future spot rate, then the UIP condition is identical to the CIP condition, with the exception of a possible risk premium for investors that are not risk neutral.

To test the UIP condition, I follow the literature by taking logs and ignoring small cross terms (see for example Flood and Rose (2001)) and test the equation

$$
\mathrm{s}_{\mathrm{t}+1}-\mathrm{s}_{\mathrm{t}}=\alpha+\beta\left(\mathrm{r}-\mathrm{r}^{*}\right)_{\mathrm{t}}+\varepsilon_{\mathrm{t}}
$$

where $s_{t}$ is the spot exchange rate in logs and $s_{t+1}$ is the spot exchange rate one month in the future. The null hypothesis of UIP is that $\alpha=0$ and $\beta=1$. Previous research has typically found $\beta$ to be significantly negative, however, indicating that countries with higher interest rates tend to experience appreciations, instead of depreciations as UIP requires. This is the forward puzzle.

In addition to testing each country individually, I also pool the data from each group (the euro countries and the CEEEs) to increase the sample size and power of the test. As noted by Flood and Rose (2001), such pooling of the data is valid under the null hypothesis. ${ }^{6}$

\subsection{Results}

For the euro countries, the results of the estimation of UIP equation (5) are presented in Table 5.

\footnotetext{
${ }^{6}$ Note that the pooled results allow for fixed effects across countries. To take account of the possibility that countries may be subject to correlated shocks, an alternative pooled regression was run where the cross-section means were subtracted from each period, thus removing any time-specific common shock. This demeaned regression yielded similar results to the pooled results presented in the text.
} 
Table 5: UIP tests for euro countries

\begin{tabular}{|l|ccc|ccc|}
\hline 1994:01 to 1998:12 & \multicolumn{3}{|c|}{ vs. US \$ } & \multicolumn{3}{c|}{ vS. DM } \\
& $\boldsymbol{\beta}$ & SE & $\mathbf{r}^{2}$ & $\boldsymbol{\beta}$ & SE & $\mathbf{r}^{\mathbf{2}}$ \\
\hline France & $-1.40^{*}$ & 0.85 & 0.03 & $\mathbf{- 0 . 8 5}$ & 0.83 & 0.04 \\
Netherlands & $\mathbf{- 2 . 9 0 ^ { * * }}$ & 0.86 & 0.09 & $\mathbf{- 0 . 3 1}$ & 0.76 & 0.00 \\
Spain & $\mathbf{- 0 . 3 7}$ & 0.81 & 0.00 & $\mathbf{- 0 . 8 1 ^ { * }}$ & 0.42 & 0.04 \\
Italy & $\mathbf{- 0 . 5 5}$ & 0.89 & 0.01 & $\mathbf{- 1 . 8 6 ^ { * * }}$ & 0.71 & 0.07 \\
& & & & & & \\
Pooled results & $\mathbf{- 1 . 0 7 ^ { * * }}$ & 0.45 & 0.02 & $\mathbf{- 1 . 3 5 ^ { * * }}$ & 0.40 & 0.06 \\
\hline
\end{tabular}

$*=$ significantly different from zero at the $90 \%$ level; $* *=$ significant at the $95 \%$ level $\mathrm{SE}=$ White corrected standard errors of the coefficient.

As has been commonly found in other research, the estimates here suggest that $\beta<0$, though the coefficient estimates are not always significantly different from zero. They are almost always significantly different from the UIP prediction of $\beta=1$, however. It is interesting to note that France and the Netherlands deviate more from UIP with the US than with Germany, while Spain and Italy deviate more from UIP with Germany than the US. This may reflect the notion that the Franc and Guilder were seen as being more credibly pegged to the DM during this time period than the currencies of Spain and Italy.

The results for the CEEEs are presented in Table 6.

Table 6: UIP tests for CEEEs

\begin{tabular}{|l|ccc|ccc|}
\hline 1994:01 to 2002:12 & \multicolumn{3}{|c|}{ vs. US \$ } & \multicolumn{3}{c|}{ vs. DM/euro } \\
& $\boldsymbol{\beta}$ & SE & $\boldsymbol{r}^{2}$ & $\boldsymbol{\beta}$ & SE & $\boldsymbol{r}^{2}$ \\
\hline Czech Rep. & $\mathbf{0 . 2 8}$ & 0.59 & 0.00 & $\mathbf{0 . 3 2}$ & 0.47 & 0.00 \\
Hungary & $\mathbf{0 . 6 4}$ & 0.23 & 0.09 & $\mathbf{0 . 5 4}$ & 0.27 & 0.01 \\
Poland & $\mathbf{0 . 3 2}$ & 0.25 & 0.01 & $-\mathbf{0 . 2 1}$ & 0.38 & 0.01 \\
& & & & & & \\
Pooled results & $\mathbf{0 . 4 8 ^ { * * }}$ & 0.18 & 0.04 & $\mathbf{0 . 2 8}$ & 0.20 & 0.01 \\
Pooled, ex. Hungary & $\mathbf{0 . 3 2}^{* *}$ & 0.16 & 0.02 & $\mathbf{0 . 1 7}$ & 0.22 & 0.01 \\
\hline
\end{tabular}

$*=$ significantly different from zero at the $90 \%$ level; ** = significant at the $95 \%$ level $\mathrm{SE}=$ White-corrected standard errors of the coefficient. 
While most of the estimates of $\beta$ are not significantly different from zero, none of the estimates of $\beta$ are significantly negative, in contrast to the euro country cases. Furthermore, the estimates for Hungary and the Czech Republic are insignificantly different from $\beta=1$ at the $95 \%$ confidence level, indicating a surprisingly close adherence to perfect UIP. Note that Hungary had a fixed exchange rate regime for much of this period. ${ }^{7}$ The result of significantly positive $\beta$ for Hungary is therefore perfectly consistent with the results of Flood and Rose (1996), in which they found positive betas for countries that had fixed exchange rates, but negative betas for countries with floating rates. However, even excluding Hungary from the pooled test I find a significantly positive $\beta$ against the US dollar, so the pooled results are not simply due to Hungary's fixed exchange rate regime. Note that in general, the pooled results indicate that the UIP condition was more nearly met with regard to US assets than with German assets.

The fact that the UIP estimates for the CEEEs are not negative (and in some instances are significantly positive) can be interpreted in a couple of possible ways. First, it is possible that the CEEEs have capital markets that are better integrated with world capital markets than the euro countries were during the 1990s. This possibility seems unlikely, though at a minimum this evidence suggests that the CEEEs are not substantially less integrated with world capital markets than the euro countries were during the 1990s.

Alternatively, it is possible that the closer adherence to UIP for the CEEEs is due to the later sample period. As discussed above, in previous literature there has been some evidence that UIP has held better over time, though this has been called into question by Meredith and Ma (2002). To check this hypothesis, the entire period 1994 to 2002 was split into two sub-periods,

\footnotetext{
${ }^{7}$ Hungary technically had an exchange rate regime of crawling bands, first against a basket of US dollar and DM/euro, and after January 2000 against the euro alone. According the International Financial Statistics, Poland and the Czech Republic had floating exchange rates for most of the sample period, with the exception of a period of crawling bands during 1998 and 1999.
} 
which I then tested individually. These results are presented in tables 7 and 8 . Comparing the two there is no significant increase in the estimates of $\beta$ between the two periods; indeed, in some cases $\beta$ falls in the second sample compared to the first. This suggests that these nonnegative results for the CEEEs are not simply due to the more recent time period compared to the euro country data.

Table 7: UIP tests for CEEEs, pre-1999

\begin{tabular}{|l|ccc|ccc|}
\hline 1994:01 to 1998:12 & \multicolumn{3}{|c|}{ vs. US \$ } & \multicolumn{3}{c|}{ vs. DM } \\
& $\boldsymbol{\beta}$ & SE & $\mathbf{r}^{2}$ & $\boldsymbol{\beta}$ & SE & $\boldsymbol{r}^{2}$ \\
\hline Czech Rep. & $\mathbf{0 . 6 4}$ & 1.25 & 0.01 & $\mathbf{- 1 . 1 1}$ & 0.95 & 0.01 \\
Hungary & $\mathbf{0 . 6 5}$ & 0.36 & 0.07 & $\mathbf{- 1 . 8 6}$ & 2.41 & 0.03 \\
Poland & $\mathbf{- 0 . 3 6}$ & 0.61 & 0.01 & $-\mathbf{6 . 5 0}$ & 5.80 & 0.09 \\
& & & & & & \\
Pooled results & $\mathbf{0 . 5 2 * *}$ & 0.18 & 0.04 & $\mathbf{- 0 . 4 5}$ & 0.60 & 0.00 \\
\hline
\end{tabular}

$*=$ significantly different from zero at the $90 \%$ level; $* *=$ significant at the $95 \%$ level $\mathrm{SE}=$ White-corrected standard errors of the coefficient.

Table 8: UIP tests for CEEEs, post-1999

\begin{tabular}{|c|c|c|c|c|c|c|}
\hline \multirow[t]{2}{*}{ 1999:01 to $2002: 12$} & \multicolumn{3}{|c|}{ vs. US \$ } & \multicolumn{3}{|c|}{ vs. euro } \\
\hline & $\beta$ & SE & $r^{2}$ & $\beta$ & SE & $r^{2}$ \\
\hline Czech Rep. & -0.82 & 2.08 & 0.01 & 0.01 & 1.52 & 0.00 \\
\hline Hungary & 0.61 & 1.36 & 0.01 & 0.26 & 0.67 & 0.00 \\
\hline Poland & 0.12 & 0.62 & 0.00 & $-0.97^{*}$ & 0.48 & 0.05 \\
\hline Pooled results & 0.15 & 0.32 & 0.00 & -0.11 & 0.29 & 0.00 \\
\hline
\end{tabular}

$*$ = significantly different from zero at the $90 \%$ level; $* *=$ significant at the $95 \%$ level $\mathrm{SE}=$ White-corrected standard errors of the coefficient.

A final consideration to note is that these results are consistent with one of the conclusions reached by Bansal and Dahlquist (2000), as well as by Flood and Rose (2001), which is that UIP holds better for emerging markets than for developed economy markets. It is possible that the risk premium implicit in the failure of UIP is lower or less volatile in the case of 
the CEEEs than it was for the euro countries during the 1990s. The next section examines the behavior of the risk premium to address that possibility.

\section{Risk Premiums and Currency Market Efficiency}

To gain additional insight into the discrepancy between the UIP experience of the CEEEs compared to the euro countries (and most other empirical studies), I run a third set of tests that test the efficiency of the exchange rate markets. These tests follow the well-known work of Fama (1984). If currency markets are rational and efficient, the forward rate $f_{t}$ can be decomposed into the expected future spot rate and a risk premium, or $f_{t}=E_{t}\left(s_{t+1}\right)+p_{t}$, where $p_{t}$ is the risk premium at time $\mathrm{t}$.

Two equations are estimated:

$$
\begin{aligned}
& \left(f_{t}-s_{t+1}\right)=\alpha_{1}+\beta_{1}\left(f_{t}-s_{t}\right)+\varepsilon_{1 t} \\
& \left(s_{t+1}-s_{t}\right)=\alpha_{2}+\beta_{2}\left(f_{t}-s_{t}\right)+\varepsilon_{2 t}
\end{aligned}
$$

where $\left(f_{t}-s_{t+1}\right)$ is the ex-post forecast error, $\left(f_{t}-s_{t}\right)$ is the forward premium, and $\left(s_{t+1}-s_{t}\right)$ is the actual ex-post change in the spot rate. All variables are expressed as natural logs.

The first equation tests whether the forward premium can systematically predict the forecast error. The second equation tests whether the forward premium is a predictor of future changes in the spot rate. As pointed out by Fama (1984), the relative size of coefficients $\beta_{1}$ and $\beta_{2}$ contains information about the relative variances of the risk premium versus the variance of the change in the spot exchange rate.

The results of estimating equations (6) and (7) for the euro countries are contained in table 9. Unlike much of the earlier literature, there are no significantly negative values for $\beta_{2}$. In other words, the widely found result of a bias in the forward premium does not exist in this 
sample. ${ }^{8}$ For most of the sample, $\beta_{2}$ is not different from zero, indicating that, while the forward premium is not an effective predictor of future spot rates, at least there is no systematic bias. ${ }^{9}$

Table 9: Forward premium equations for euro countries

\begin{tabular}{|l|cccc|cccc|}
\hline 1994:01 to 1998:12 & \multicolumn{3}{|c|}{ vs. US\$ } & \multicolumn{3}{c|}{ vs. DM } \\
& $\boldsymbol{\beta}_{1}$ & $\boldsymbol{\beta}_{2}$ & $\mathbf{S E}(\boldsymbol{\beta})$ & $\boldsymbol{\beta}_{1}-\boldsymbol{\beta}_{2}$ & $\boldsymbol{\beta}_{1}$ & $\boldsymbol{\beta}_{2}$ & SE $(\boldsymbol{\beta})$ & $\boldsymbol{\beta}_{1}-\boldsymbol{\beta}_{2}$ \\
\hline France & $0.96^{* *}$ & & 0.21 & & & & 0.21 & \\
& & 0.04 & & $0.92^{* *}$ & $0.53^{* *}$ & $0.47^{* *}$ & & 0.06 \\
Netherlands & $1.28^{* *}$ & -0.28 & 0.22 & $1.56^{* *}$ & $0.38^{*}$ & $0.62^{* *}$ & 0.21 & -0.24 \\
Spain & $1.30^{* *}$ & -0.30 & 0.20 & $1.60^{* *}$ & $1.23^{* *}$ & -0.23 & 0.42 & $1.46^{*}$ \\
Italy & $1.22^{* *}$ & -0.22 & 0.56 & 1.44 & $1.17^{* *}$ & -0.17 & 0.19 & $1.34^{* *}$ \\
& & & & & & & & \\
Pooled results & $1.17^{* *}$ & -0.17 & 0.11 & $1.34^{* *}$ & $1.10^{* *}$ & -0.10 & 0.13 & $1.20^{* *}$ \\
\hline
\end{tabular}

$*$ = significantly different from zero at the $90 \%$ level; $* *=$ significant at the $95 \%$ level $\mathrm{SE}=$ standard error of $\beta_{1}$ and $\beta_{2}$.

However, it is still the case, as has been found in most earlier studies, that $\beta_{1}-\beta_{2}$ is positive for most countries (at least against the US dollar), indicating that variance in the forward premium is more due to variance in the risk premium than to expected changes in the exchange rate. This is less the case against the DM, where less of the variance of the forward premium is due to changes in the risk premium. This finding supports the conclusion of DeGrauwe (1996), who argued that the greater credibility of fixed exchange rate regimes causes reduced volatility of risk premiums in such cases.

Again using these results for the euro countries as a benchmark, I next estimate the same equations for the CEEEs. Those results are presented in the table below.

\footnotetext{
${ }^{8}$ See Engel (1995) for a survey of the previous literature with the consistent finding of a negative coefficient. ${ }^{9}$ As shown by Fama (1984), the two equations contain much of the same information, so the coefficients $\beta_{1}$ and $\beta_{2}$ must sum to one, and have the same standard error. Thus $\operatorname{SE}(\beta)$ in the table represents the standard error of both betas.
} 
Table 10: Forward premium equations for CEEEs

\begin{tabular}{|l|cccc|cccc|}
\hline 1997:04 to 2002:12 & \multicolumn{3}{|c|}{ vs. US\$ } & \multicolumn{3}{c|}{ vs. DM/euro } \\
& $\boldsymbol{\beta}_{1}$ & $\boldsymbol{\beta}_{2}$ & $\mathbf{S E}(\boldsymbol{\beta})$ & $\boldsymbol{\beta}_{1}-\boldsymbol{\beta}_{2}$ & $\boldsymbol{\beta}_{1}$ & $\boldsymbol{\beta}_{2}$ & SE( $\boldsymbol{\beta})$ & $\boldsymbol{\beta}_{1}-\boldsymbol{\beta}_{2}$ \\
\hline Czech Rep. & $0.94^{* *}$ & 0.06 & 0.33 & 0.88 & 0.07 & $0.93^{* *}$ & 0.39 & -0.86 \\
Hungary & $1.22^{* *}$ & -0.22 & 0.24 & $1.44^{* *}$ & $0.38^{*}$ & $0.62^{* *}$ & 0.21 & -0.24 \\
Poland & $2.22^{* *}$ & -1.22 & 1.09 & 3.44 & $1.37^{* *}$ & -0.37 & 0.47 & $1.74^{*}$ \\
& & & & & & & & \\
Pooled results & $1.01^{* *}$ & -0.01 & 0.19 & $1.02^{* *}$ & $0.33^{* *}$ & $0.67^{* *}$ & 0.16 & -0.34 \\
\hline
\end{tabular}

$*$ = significantly different from zero at the $90 \%$ level; $* *=$ significant at the $95 \%$ level $\mathrm{SE}=$ standard error of $\beta_{1}$ and $\beta_{2}$.

First of all, we fail to find a bias in the forward premium, just as was the case for the euro countries. Estimates of $\beta_{2}$ are always either insignificantly different from zero, or else significantly positive. In fact, consistent with the results of the UIP estimation presented in table 6, the estimates of $\beta_{2}$ are not significantly different from the perfect UIP result of $\beta_{2}=1$ for Hungary and the Czech Republic against the DM/euro. The exchange rate markets, which seem to have improved the efficiency of their forecasts for the euro countries during the late 1990s, also seem to have eliminated any systematic bias in the forward rates of the CEEEs.

Secondly, against the US dollar, it appears that, like the euro countries, most of the variance of the forward premium is due to changes in the risk premium, not expected changes in the spot rate. However, against the DM and euro, it seems that the forward premiums of the CEEEs vary more due to changes in the expected future spot rate than to changes in the risk premiums. The implication is that the risk premiums of the CEEE currencies behaves rather similarly to the risk premiums of the euro countries during the five years preceding the introduction of the euro. Put another way, the exchange rates of the CEEEs against the euro are perceived by the markets as nearly as stable as the pre-1999 ERM was for the euro countries, so that risk premiums display little volatility. 


\section{Conclusions}

Each of the three sets of tests run in this paper provide different pieces of evidence toward understanding how well integrated the capital markets of the CEEEs are with those of Western Europe and the US. The overall conclusion is that, according to the tests used in this paper, the capital markets and exchange rate markets look very similar to those of the euro countries during the years leading up to the introduction of the euro.

The CIP tests found that reversion to CIP holds for the CEEEs just as well as it did for the euro countries. Reversion to CIP after a temporary deviation is faster in the euro currency markets than the dollar market, just as was the case for the pre-1999 euro countries. This suggests a level of basic capital market integration for the CEEEs comparable to that of the euro countries in the late 1990s.

The UIP tests found that the UIP condition holds better for the CEEEs than for the euro countries pre-1999. This result is consistent with other work that has shown that UIP holds better for emerging markets than for developed country markets. The implication is that risk premiums behave differently in the case of the CEEEs than for the euro countries in the 1990s. This is the one way in which the exchange rate markets of the CEEEs seem to differ slightly from the pre-1999 euro countries. However, the surprisingly close adherence to UIP provides further evidence of capital markets that are closely integrated with the EU.

Finally, the efficiency of the forward markets in the CEEEs was compared to that of the euro countries, and the technique pioneered by Fama (1984) was used to assess the behavior of risk premiums in those countries. These tests showed that the forward premiums of the CEEE currencies were not biased predictors of the future spot rate, unlike most previous findings, but exactly like estimates for the euro countries during the latter half of the 1990s. Secondly, the 
volatility of the forward premiums was shown to be due more to variance in the expected exchange rate than variance in the risk premiums, also like the pre-1999 euro countries.

These results provide a general picture of capital markets and exchange rates for the CEEEs that exhibit behavior that is extremely similar to that of the euro countries during the period immediately preceding the introduction of the euro. This provides evidence that the capital markets of the CEEEs have apparently followed very closely in the footsteps of the other euro countries. One can therefore reasonably hope that the next steps that the emerging economies of Central Europe take - full accession into the EU and adoption of the euro - should not be overly difficult. 


\section{Bibliography}

Bansal, Ravi and Dahlquist, Magnus, 2000. "The Forward Premium Puzzle: Different Tales from Developed and Emerging Economies," Journal of International Economics, vol. 51.

Choudry, Taufiq, 1999. "Re-examining forward market efficiency" International Review of Economics and Finance, Vol. 8, Issue 4, 1999.

Claessens, Stijn; Oks, Daniel; and Polassi, Rossana, 1998. "Capital Flows to Eastern and Central Europe and the Former Soviet Union," World Bank Policy Research Working Paper \#1976, September 1998.

De Grauwe, Paul, 1989. "On the Nature of Risk in the Foreign Exchange Markets" CEPR Discussion Paper \# 326, Nov. 1989.

De Grauwe, Paul, 1996. International Money, $2^{\text {nd }}$ edition, Oxford Press.

Dickinson, David and Mullineux, Andrew, 2001. "Financial Integration Between the EU and the Economies of Central and Eastern Europe: An Overview" in Financial and Monetary Integration in the New Europe, Dickinson and Mullineux (eds.), Edward Elgar Press.

Engel, Charles, 1995. "The Forward Discount Anomaly and the Risk Premium: A Survey of Recent Evidence." National Bureau of Economic Research Working Paper no. 5312.

Flood, Robert and Rose, Andrew, 1996. "Fixes: Of the Forward Discount Puzzle" Review of Economics and Statistics, pp. 748-752.

Holmes, Mark J., 2001. "Some new evidence on exchange rates, capital controls and European Union financial integration" International Review of Economics and Finance, Vol. 11, 2001.

Holmes, Mark J. \& Wu, Yangru, 1997. "Capital Controls and Covered Interest Parity in the EU: Evidence from a Panel-Data Unit Root Test" Weltwirtschaftliches Archiv, Vol. 122, No. $1,1997$.

Lemmen, Jan, 1998. Integrating Financial Markets in the European Union, Edward Elgar Press.

Meredith, Guy and Ma, Yue, 2002. "The Forward Premium Puzzle Revisited,” IMF Working Paper, February 2002.

Obstfeld, Maurice (1995), "International Capital Mobility in the 1990s," in Peter Kenen (ed.), Understanding Interdependence: the Macroeconomics of the Open Economy. Princeton University Press 1995.

Rovna, Lenka Anna. "The Enlargement of the European Union: The Case of the Czech Republic". Perspectives on European Politics and Society Vol. 2, No. 1, 2001. 


\section{CESifo Working Paper Series}

(for full list see www.cesifo.de)

957 Edward Castronova, The Price of 'Man' and 'Woman': A Hedonic Pricing Model of Avatar Attributes in a Synthetic World, June 2003

958 Laura Bottazzi and Marco Da Rin, Financing Entrepreneurial Firms in Europe: Facts, Issues, and Research Agenda, June 2003

959 Bruno S. Frey and Matthias Benz, Being Independent is a Great Thing: Subjective Evaluations of Self-Employment and Hierarchy, June 2003

960 Aaron Tornell and Frank Westermann, Credit Market Imperfections in Middle Income Countries, June 2003

961 Hans-Werner Sinn and Wolfgang Ochel, Social Union, Convergence and Migration, June 2003

962 Michael P. Devereux, Measuring Taxes on Income from Capital, June 2003

963 Jakob de Haan, Jan-Egbert Sturm and Bjørn Volkerink, How to Measure the Tax Burden on Labour at the Macro-Level?, June 2003

964 Harry Grubert, The Tax Burden on Cross-Border Investment: Company Strategies and Country Responses, June 2003

965 Kirk A. Collins and James B. Davies, Measuring Effective Tax Rates on Human Capital: Methodology and an Application to Canada, June 2003

966 W. Steven Clark, Using Micro-Data to Assess Average Tax Rates, June 2003

967 Christopher Heady, The 'Taxing Wages' Approach to Measuring the Tax Burden on Labour, June 2003

968 Michael P. Devereux and Alexander Klemm, Measuring Taxes on Income from Capital: Evidence from the UK, June 2003

969 Bernhard Eckwert and Itzhak Zilcha, The Effect of Better Information on Income Inequality, June 2003

970 Hartmut Egger and Josef Falkinger, The Role of Public Infrastructure for Firm Location and International Outsourcing, June 2003

971 Dag Morten Dalen and Trond E. Olsen, Regulatory Competition and Multi-national Banking, June 2003 
972 Matthias Wrede, Tax Deductibility of Commuting Expenses and Residential Land Use with more than one Center, June 2003

973 Alessandro Cigno and Annalisa Luporini, Scholarships or Student Loans? Subsidizing Higher Education in the Presence of Moral Hazard, June 2003

974 Chang Woon Nam, Andrea Gebauer and Rüdiger Parsche, Is the Completion of EU Single Market Hindered by VAT Evasion?, June 2003

975 Michael Braulke and Giacomo Corneo, Capital Taxation May Survive in Open Economies, July 2003

976 Assar Lindbeck, An Essay on Welfare State Dynamics, July 2003

977 Henrik Jordahl and Luca Micheletto, Optimal Utilitarian Taxation and Horizontal Equity, July 2003

978 Martin D. D. Evans and Richard K. Lyons, Are Different-Currency Assets Imperfect Substitutes?, July 2003

979 Thorsten Bayindir-Upmann and Frank Stähler, Market Entry Regulation and International Competition, July 2003

980 Vivek Ghosal, Firm and Establishment Volatility: The Role of Sunk Costs, Profit Uncertainty and Technological Change, July 2003

981 Christopher A. Pissarides, Unemployment in Britain: A European Success Story, July 2003

982 Wolfgang Buchholz, Richard Cornes, and Wolfgang Peters, On the Frequency of Interior Cournot-Nash Equilibria in a Public Good Economy, July 2003

983 Syed M. Ahsan and Panagiotis Tsigaris, Choice of Tax Base Revisited: Cash Flow vs. Prepayment Approaches to Consumption Taxation, July 2003

984 Campbell Leith and Jim Malley, A Sectoral Analysis of Price-Setting Behavior in US Manufacturing Industries, July 2003

985 Hyun Park and Apostolis Philippopoulos, Choosing Club Membership under Tax Competition and Free Riding, July 2003

986 Federico Etro, Globalization and Political Geography, July 2003

987 Dan Ariely, Axel Ockenfels and Alvin E. Roth, An Experimental Analysis of Ending Rules in Internet Auctions, July 2003

988 Paola Conconi and Carlo Perroni, Self-Enforcing International Agreements and Domestic Policy Credibility, July 2003

989 Charles B. Blankart and Christian Kirchner, The Deadlock of the EU Budget: An Economic Analysis of Ways In and Ways Out, July 2003 
990 M. Hasham Pesaran and Allan Timmermann, Small Sample Properties of Forecasts from Autoregressive Models under Structural Breaks, July 2003

991 Hyun Park, Apostolis Philippopoulos and Vangelis Vassilatos, On the Optimal Size of Public Sector under Rent-Seeking competition from State Coffers, July 2003

992 Axel Ockenfels and Alvin E. Roth, Late and Multiple Bidding in Second Price Internet Auctions: Theory and Evidence Concerning Different Rules for Ending an Auction, July 2003

993 Pierre Salmon, The Assignment of Powers in an Open-ended European Union, July 2003

994 Louis N. Christofides and Chen Peng, Contract Duration and Indexation in a Period of Real and Nominal Uncertainty, July 2003

995 M. Hashem Pesaran, Til Schuermann, Björn-Jakob Treutler, and Scott M. Weiner, Macroeconomic Dynamics and Credit Risk: A Global Perspective, July 2003

996 Massimo Bordignon and Sandro Brusco, On Enhanced Cooperation, July 2003

997 David F. Bradford, Addressing the Transfer-Pricing Problem in an Origin-Basis X Tax, July 2003

998 Daniel Gros, Who Needs Foreign Banks?, July 2003

999 Wolfram Merzyn and Heinrich W. Ursprung, Voter Support for Privatizing Education: Evidence on Self-Interest and Ideology, July 2003

1000 Jo Thori Lind, Fractionalization and the Size of Government, July 2003

1001 Daniel Friedman and Donald Wittman, Litigation with Symmetric Bargaining and TwoSided Incomplete Information, July 2003

1002 Matthew Clarke and Sardar M. N. Islam, Health Adjusted GDP (HAGDP) Measures of the Relationship Between Economic Growth, Health Outcomes and Social Welfare, July 2003

1003 Volker Grossmann, Contest for Attention in a Quality-Ladder Model of Endogenous Growth, August 2003

1004 Marcel Gérard and Joan Martens Weiner, Cross-Border Loss Offset and Formulary Apportionment: How do they affect multijurisdictional firm investment spending and interjurisdictional tax competition?, August 2003

1005 Burkhard Heer, Nonsuperneutrality of Money in the Sidrauski Model with Heterogeous Agents, August 2003 
1006 V. Anton Muscatelli, Piergiovanna Natale, and Patrizio Tirelli, A Simple and Flexible Alternative to the Stability and Growth Pact Deficit Ceilings. Is it at hand?, August 2003

1007 Reto Foellmi and Josef Zweimüller, Inequality and Economic Growth: European Versus U.S. Experiences, August 2003

1008 James S. Costain and Michael Reiter, Business Cycles, Unemployment Insurance, and the Calibration of Matching Models, August 2003

1009 Marco Runkel, Optimal Contest Design when the Designer's Payoff Depends on Competitive Balance, August 2003

1010 Donald O. Parsons, Torben Tranaes and Helene Bie Lilleør, Voluntary Public Unemployment Insurance, August 2003

1011 Rüdiger Pethig and Andreas Wagener, Profit Tax Competition and Formula Apportionment, August 2003

1012 Johan Willner, Privatisation and Public Ownership in Finland, August 2003

1013 Seppo Kari and Jouko Ylä-Liedenpohja, Taxation and Valuation of International Real Investments, August 2003

1014 James Heckman, Rosa Matzkin and Lars Nesheim, Simulation and Estimation of Hedonic Models, August 2003

1015 Biswa N. Bhattacharyay, Towards a Macro-Prudential Leading Indicators Framework for Monitoring Financial Vulnerability, August 2003

1016 J. Stephen Ferris and Stanley L. Winer, Searching for Keynes: With Application to Canada, 1870-2000, August 2003

1017 Massimo Bordignon, Luca Colombo and Umberto Galmarini, Fiscal Federalism and Endogenous Lobbies' Formation, August 2003

1018 Annette Alstadsæter, The Dual Income Tax and Firms'Income Shifting through the Choice of Organizational Form and Real Capital Investments, August 2003

1019 Peter Fredriksson and Bertil Holmlund, Optimal Unemployment Insurance Design: Time Limits, Monitoring, or Workfare?, August 2003

1020 Kashif S. Mansori, Following in their Footsteps: Comparing Interest Parity Conditions in Central European Economies to the Euro Countries, August 2003 